\title{
Higher Education Should Have A Role In The Workforce Development System
}

Gregory W. Ulferts (E-mail: ulfertgw@udmercy.edu), University of Detroit Mercy

Larry Bossman (E-mail: bossmalj@udmercy.edu), University of Detroit Mercy

Phyllis Eisen, Center for Workforce Success, National Association of Manufacturers

\begin{abstract}
In order to understand the Workforce Development System, we propose to review the history of the current workforce development system, discuss models and initiatives that are evolving, and conclude with a discussion on how higher education can be involved in research, community partnership, and programmatic activities.
\end{abstract}

\section{The Changing Challenges Of Workforce Development}

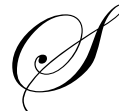

ince the 1960s, when the Manpower Development and Training Act (MDTA) created the public workforce-development (WFD) system, those concerned with helping the disadvantaged to find success in the labor market have hoped for the sustained and systematic involvement of employers - especially those with good jobs and family-supporting career potential - in that system. In the subsequent decades, with some notable exceptions, that hope has not been adequately realized. The commonly cited reasons include:

- In the loose labor markets that prevailed until the mid-1990s, most employers did not need to involve themselves deeply with the public WFD system. They could meet their labor needs adequately though other labor market mechanisms.

- $\quad$ The public WFD system was focused on the disadvantaged, who had often had multiple barriers to successful employment. Further, the public WFD system generally offered only short-term employment preparation, which many employers, especially those with "good" jobs requiring higher skills, found inadequate. Finally, employers complained of bureaucracy, politics, and poor quality programs in the public WFD system.

There may be another reason: there was scant effort to reach out to and systematically structure the engagement of the employer community in the WFD system, in particular, by building on the natural peer structures of employer associations in local communities. What was needed - and lacking - was an effort to develop an American equivalent of the role of Kammers, or "chambers" that systematically engage employers in WFD in parts of Europe.

In loose labor markets, such an effort was not likely to succeed, but in the mid-1990s unemployment rates plunged to levels not seen in generations as the economy entered an almost unprecedented period of prolonged expansion. With labor shortages reaching crisis proportions, employers - and their associations - began to seek ways of reaching out to "non-traditional populations" of many kinds, including the poverty-stricken who were previously routinely screened out of consideration. This presented a window of opportunity of historic proportions to "build employers" into the WFD system. Even in the current economic pause, that window generally remains open, as unemployment has edged only slightly upwards. Moreover, the need for new structures to involve employers in WFD for entry-level workers is built into both the economy and its demographics - we need to restock an aging workforce and reskill all workers for increasingly technologically driven work in the face of global competition. Developing a more effective employer role in WFD is thus important on many dimensions. 


\section{The NAM's Response}

The National Association of Manufacturers (NAM) is the nation's largest multi-industry trade association, representing 14,000 member companies (including 10,000 small and mid-sized manufacturers) and 350 member associations serving manufacturers and employees in every industrial sector and all 50 states. The 350 member associations of the NAM are divided into three major groups:

- $\quad$ The Employer Association Group (EAG) comprises 69 independent local and regional employer and manufacturing associations representing more than 50,000 individual employers. These local and regional affiliates offer a broad range of human-resource services generally aimed at managers, supervisors and other personnel.

- $\quad$ The State Associations Group (SAG) comprises 47 associations functioning at the state level and enrolling more than 117,000 companies. These associations' activities focus largely on legislation and policy setting at the state and national levels.

- The Associations Council (AC) includes more than 220 manufacturing trade associations representing more than 60,000 firms in every manufacturing sector. These sectoral associations and the council are concerned with legislative, regulatory, economic and education policy matters that affect their interests.

It is important to note that the NAM body of associations comprises both sectoral and general employer membership bodies. The SAG and AC members generally represent manufacturers and the sub-sectors of manufacturing; the EAG members usually serve diverse employers in all sectors in a region (as many as half their members may be from public, nonprofit, and service sectors who join EAG associations to benefit from the human resource services they provide).

The NAM has traditionally focused on legislation and policy issues at the national level. In the mid-1990s, however, it established the Center for Workforce Success (CWS) in its nonprofit, 501c(3) affiliate, the Manufacturing Institute. The mission of CWS is to find and promote workforce solutions for manufacturers in a global economy and to make manufacturing a preferred career choice for Americans in the $21^{\text {st }}$ century. This is a new and stilldeveloping set of activities for the NAM.

From the outset, much (though not all) of CWS's work has focused on identifying and developing the role that businesses and employer associations can play in workforce development, especially but not only at the lower levels of internal labor markets. CWS has stressed the critical potential of employer associations as workforce development intermediaries and outlined that role in its publication, Making the Connections: The Role of Employer Associations in Workforce Development (see attached). CWS has also produced two series of case studies on associations that are beginning to play this intermediary role - one on five associations attempting to enroll small manufacturers in School-to-Career programs and the other on five innovative efforts by employers and associations to reach into inner-city poverty populations to develop productive workers.

\section{CWS's Workforce Development Initiatives}

CWS's work has focused on promoting manufacturers' involvement in school-to-career activities and on developing the employer association WFD intermediary role. Workforce Innovation Networks (WINs) is in its fourth year as a partnership of CWS/NAM; the Center for Workforce Preparation of the U.S. Chamber of Commerce; and Jobs or the Future (JFF), a national non-profit policy, advocacy, and demonstration organization headquartered in Boston. WINs has been funded to date by The Ford Foundation, the Annie E. Casey Foundation, and the John D. and Catherine T. MacArthur Foundation. WINs has several programmatic elements all aimed at fostering the employer association WFD intermediary role, chiefly among general membership employer associations (e.g., NAM's EAG and some SAG associations and local chambers of commerce).

WINs is presently mounting a new program initiative. Each of the WINs partners is mounting two or three intense demonstration projects: 
- $\quad$ CWS/NAM is mounting three demonstration projects to explore the ability of employer association WFD intermediaries to assist member firms to retain and advance disadvantaged entry-level workers.

- The Center for Workforce Preparation will assist three local chambers to improve the governance and performance of local Workforce Investment Boards.

- JFF will work with two or three associations to demonstrate a "skill supply chain" model that will move low-wage, low-skill workers through a sequence of jobs to develop skills and higher earning power.

In addition, CWS is strategically exploring ways to further develop the WFD intermediary role of the NAM's 220-plus sectoral associations, which represent a broad range of career possibilities, generally with familysupporting wages and full benefits.

\section{Conclusion}

Higher education needs to explore areas of possible mutual interest and action. We propose that the dialogue review the history of the current workforce development system, discuss models and initiatives that are evolving, and conclude with a discussion on how higher education can be involved in research, community partnership, and programmatic activities. The role of the community college system is becoming clear to many employers but the role of universities needs to be discussed. We believe this discussion also will lead into a dialogue on the importance of competitive businesses and the career opportunities available in manufacturing and technology. 
Notes 